\title{
MODEL KONSEPTUAL MEDIA MOTION GRAPHIC INTERAKTIF MATEMATIKA UNTUK SISWA KELAS V SEKOLAH DASAR
}

\author{
Titik Putri Wardaniasih $^{1}$, Siti Rohmi Yuliati², Ika Lestari $^{3}$ \\ Universitas Negeri Jakarta \\ Email :titikputriw@gmail.com ${ }^{1}$, sitirohmiyuliati@unj.ac.id ${ }^{2}$,ikalestari@unj.ac.id ${ }^{3}$
}

\begin{abstract}
The purpose of this research is to find out a conceptual model as a fundamental in learning development of Mathematics using graphic media. In this research, we have used Hannapin and Peck's model which consists of three stages i.e. requirements analysis, design, and development or implementation. This research was implemented at SDN Karanggan 01 Gunung Putri, Bogor towards fifth-grade students of elementary schools. According to the observation, the product feasibility trial shows that interactive motion graphic media is very feasible to be used. It is confirmed that, by an average expert review rating of $95.14 \%$ that belongs to "Very Good". Hence, based on the previous result, the conceptual model of interactive motion graphic media is effective to be used in schools to improve mathematics understanding.
\end{abstract}

Keyword : conceptual model, motion graphic, mathematic, scale

\begin{abstract}
Abstrak
Tujuan dari penelitian ini adalah untuk menemukan model konseptual sebagai dasar dalam mengembangkan suatu media pembelajaran Matematika materi Skala menggunakan media motion graphic. Model pengembangan yang digunakan pada penelitian ini adalah model Hannapin dan Peck yang terdiri dari tiga tahapan yaitu analisis kebutuhan, desain, dan pengembangan atau implementasi. Penelitian ini dilaksanakan di SDN Karanggan 01 Gunung Putri, Bogor terhadap siswa kelas V sekolah dasar. Hasil uji coba kelayakan produk menunjukkan bahwa media motion graphic interaktif sangat layak digunakan dengan mendapat penilaian expert review rata-rata sebesar 95,14\% dengan kategori "Sangat Baik". Berdasarkan analisis terhadap temuan penelitian sebelumnya model konseptual media motion graphic interaktif yang peneliti temukan efektif digunakan pada sekolah dengan permasalahan yang peneliti temukan di lapangan.
\end{abstract}

Kata Kunci : model konseptual, motion grafic, matematika, skala

\section{PENDAHULUAN}

Matematika merupakan induk ilmu pengetahuan dan memiliki peran penting dalam kemajuan suatu bangsa. Matematika telah digunakan sebagai alat penting diberbagai bidang, termasuk ilmu alam, teknik, kedokteran atau medis, dan ilmu pengetahuan sosial seperti ekonomi. Mengingat pentingnya peran Matematika bagi kehidupan manusia dan kemajuan bangsa sudah seharusnya para pendidik menaruh perhatian lebih pada mata pelajaran Matematika sejak usia sekolah dasar.

Pada kenyataannya, berdasarkan observasi yang dilakukan di SDN Menteng 03 Kecamatan Cikini Kota Jakarta Pusat pada bulan september 2019 dan observasi di SDN Karanggan 01 kecamatan Gunung Putri Kabupaten Bogor pada bulan agustus 2019, saat berlangsungnya proses pembelajaran 
Matematika, siswa terlihat kurang antusias mengikuti pembelajaran dan menyebabkan siswa menjadi kurang fokus sehingga daya ingat siswa terhadap pembelajaran Matematika tidak bertahan lama dan menyebabkan hasil belajar Matematika menjadi di bawah rata-rata nilai yang telah ditetapkan sekolah. Hal tersebut tentunya menjadi masalah bagi para pendidik untuk meningkatkan kualitas belajar Matematika siswa di sekolah dasar.

Setelah melakukan pengamatan di sekolah dasar dan wawancara terhadap guru kelas, ditemukan beberapa faktor yang membuat mata pelajaran Matematika sedikit diminati oleh sebagian besar siswa yaitu, pertama, kurangnya media pembelajaran yang sesuai dengan karakteristik belajar anak. Kedua, metode pembelajaran yang digunakan oleh para pendidik kerap kali membosankan, kurang memanfaatkan perkembangan teknologi, dan tidak menjadikan siswa aktif selama proses pembelajaran. Ketiga, setelah mewawancarai beberapa siswa terkait pembelajaran Matematika di kelas, tidak sedikit peserta didik mengeluh terkait cara penyelesaian soal Matematika yang sangatlah panjang dan berbelit-belit sehingga menjadikan siswa merasa kesulitan dan tidak termotivasi untuk menyelesaikannya.

Hasil wawancara yang telah dilakukan kepada guru kelas V SDN Karanggan 01 kecamatan Gunung Putri Kabupaten Bogor mengenai materi Matematika yang menjadi masalah bagi sebagian besar siswa salah satunya yaitu materi Skala. Hasil belajar siswa pada materi Skala masih jauh di atas rata-rata. Berdasarkan rekapan nilai rata-rata di kelas VA dan VB hanya mencapai nilai 60, sedangkan KKM pada mata pelajaran Matematika di SDN Karanggan 01 adalah 75. Hal tersebut terjadi karena pembelajaran materi Skala jarang sekali dilaksanakan dengan bantuan media. Guru hanya mengandalkan buku sebagai sumber belajar satu-satunya sehingga siswa menjadi kurang termotivasi untuk mempelajarinya dan tidak mendorong siswa untuk belajar mandiri secara langsung.

Peneliti berusaha untuk menemukan suatu model konseptual yang nantinya dapat digunakan sebagai dasar dalam mengembangkan suatu media pembelajaran untuk mata pelajaran Matematika yang terkesan sulit bagi siswa menjadi hal yang menyenangkan untuk dipelajari, maka 
dari itu, akan dibuat model konseptual dari media motion graphic.

Pemilihan media motion graphic didasari oleh kebutuhan terciptanya suatu media pembelajaran yang efektif dan efesien. Media motion graphic yang akan dikembangkan diharapkan dapat menjadi alternatif lain bagi guru untuk menyampaikan materi Skala selain dengan menggunakan buku, memberikan pengalaman belajar yang berbeda bagi peserta didik khususnya pada materi Skala, dapat digunakan kapan saja dan dimana saja juga tidak akan rusak oleh waktu.

Terdapat beberapa hasil penelitian yang telah dilakukan sebelumya mengenai penggunaan model konseptual media animasi motion graphic untuk siswa di sekolah dasar yang berjudul "Pengembangan Motion Graphic Pembelajaran Mata Pelajaran Pendidikan Kewarganegaraan Kelas I Sekolah Dasar", pada artikel tersebut membuktikan bahwa motion graphic pembelajaran yang dikembangkan efektif dan dapat melatih keterampilan berpikir kritis siswa (Purwanti, 2015). Persamaan dari model konseptual tersebut dengan model konseptual yang akan dilakukan adalah penataan teks motion graphic yang digunakan selain secara audio juga ditampilkan melalui screen teks sehingga membantu peserta didik yang mengalami permasalahan terhadap indera pendengaran, sedangkan perbedaan media motion graphic tersebut terhadap media motion graphic yang akan peneliti kembangkan adalah penggunaan media motion graphic dilengkapi media pendukung lembar latihan soal yang diinstruksikan dalam motion graphic.

Penelitian lainnya yang telah dilakukan adalah penelitian yang berjudul Perancangan Video Infografis Bahaya Merokok untuk Anak SD Menggunakan Teknik Motion Graphic. Dalam penelitian tersebut menghasilkan video infografis bahaya merokok untuk anak sekolah dasar yang layak untuk dipublikasikan sebagai pengetahuan dan sarana edukasi untuk anak SD tentang bahaya rokok (Oktaviani, 2018). Persamaan dari penelitian tersebut adalah menerapkan teknik motion graphic dan perbedaannya adalah konten yang disampaikan merupakan infografis tentang bahaya merokok.

Selanjutnya, penelitian yang telah dilakukan mengenai media motion graphic untuk usia sekolah dasar adalah penelitian berjudul "Pembuatan Motion Graphic Untuk Memperkenalkan 
Perpustakaan Kepada Siswa Sekolah

Dasar Dalam Bentuk Video”. Penelitian tersebut menghasilkan video motion graphic yang dijadikan sebagai sarana penambah wawasan dan ilmu pengetahuan mengenai perpustakaan (Gusman, 2018). Persamaan penelitian tersebut adalah dengan penelitian ini adalah memanfaat software pendukung yang sama yaitu Adobe After Effect, Adobe Premiere, dan Adobe Ilustrator. Perbedaan penelitian tersebut dengan penelitian ini adalah seri software yang digunakan, jika pada penelitian tersebut menggunakan Adobe CC 2017, penelitian ini menggunakan Adobe $C C$ 2019.

Penelitian berikutnya yang telah dilakukan adalah penelitian berjudul "Perancangan Animated Motion Graphic Sebagai Media Alternatif Pembelajaran Anak Tunagrahita". Penelitian tersebut mengembangkan media motion graphic yang berisi materi bina diri dalam mempelajari tata cara makan dan menggunakan peralatan makan, media ini juga diperuntukkan untuk membantu pengajar maupun orangtua dalam menyampaikan materi bina diri secara visual sebagai sarana yang dapat membantu anak tunagrahita dalam proses belajar mengajar (Miranti, 2017).
Persamaan media motion graphic dalam penelitian tersebut dengan penelitian ini adalah menggunakan flat design. Perbedaan dengan motion graphic dalam penelitian ini adalah gerakan yang dibuat bertempo normal, berbeda dengan motion graphic dalam penelitian tersebut yaitu setiap gerakan dibuat lebih lamban dari motion graphic pada umumnya agar anak tunagrahita mampu memahami materi yang diberikan.

Penelitian yang sebelumnya telah dilakukan lainnya yaitu penelitian berjudul "Motion Graphic Mitigasi Bencana Gempa Bumi Untuk Anak SD Di Kota Padang". Penelitian tersebut merancang iklan layanan masyarakat tentang mitigasi bencana gempa bumi ini dirancang dengan tujuan agar anak SD di kota Padang mengerti atau memahami upaya pengurangan resiko bencana (mitigasi) yang harus dilakukan pada saat bencana terjadi (Arindi, 2019). Persamaan penelitian tersebut dengan penelitian ini adalah gaya desain yang diterapkan adalah gaya flat design karena simpel dan menggunakan perpaduan warna-warna cerah yang disukai anak-anak sedangkan, perbedaannya dengan penelitian ini adalah isi materi dalam video motion graphic. Dalam penelitian ini isi materi 
motion graphic yang dikembangkan adalah materi pembelajaran Matematika yaitu Skala.

Berdasarkan pengamatan terhadap permasalahan yang terdapat di sekolah dasar khususnya pada mata pelajaran Matematika materi Skala di kelas V dan keberhasilan dan kekurangan terhadap penelitian sebelumnya terkait penggunaan media motion graphic untuk siswa usia sekolah dasar sehingga menghantarkan untuk menemukan model konseptual dari media pembelajaran motion graphic pada materi Skala. Adapun judul yang dilakukan oleh peneliti adalah "Model Konseptual Media Motion Graphic Interaktif Matematika Pada Materi Skala Menggunakan Adobe After Effect CC 2019 Untuk Siswa Kelas V Sekolah Dasar".

\section{METODOLOGI PENELITIAN}

Penelitian ini dilaksanakan di SDN Karanggan 01 kelas V yang berlokasi di J1. Karanggan No. 155, Desa Karanggan, Kecamatan Gunungputri, Kabupaten Bogor, Jawa Barat. Kegiatan penelitian model konseptual ini dilaksanakan pada semester ganjil tahun ajaran 2019-2020 terhitung mulai bulan September sampai Januari 2020. Metode penelitian ini merupakan

$$
\text { penelitian }
$$

dan pengembangan (research and development) dengan menggunakan model pengembangan Hannapin dan Pack. Adapun langkah-langkah yang dilakukan peneliti dalam penelitian dan pengembangan ini yaitu: analisis kebutuhan, desain, pengembangan dan implementasi (Hamzah, 2019).

Media pembelajaran yang peneliti kembangkan merupakan media motion graphic interaktif Matematika materi Skala untuk siswa kelas V SD yang dibuat menggunakan software adobe after effect cc 2019. Motion graphic yang peneliti kembangkan dilengkapi dengan latihan soal dan juga exercise paper untuk melatih keterampilan siswa.

Teknik pengumpulan data yang digunakan dalam penelitian model konseptual media motion graphic materi Skala ini dilaksanakan melalui kegiatan observasi sekolah, wawancara analisis kebutuhan terhadap guru kelas dan siswa kelas V SD, dan kuisioner untuk expert review yaitu ahli media, ahli materi, dan ahli bahasa.

Teknik analisis data yang digunakan dalam penelitian dan pengembangan ini adalah statistik deskriptif kuantitatif. Tujuannya adalah untuk menyederhanakan data dalam 
bentuk yang lebih mudah dibaca dan perhitungan penilaian skor rata-rata diinterprestasi. Hasil data yang telah menggunakan rumus berikut:

diperoleh kemudian dilakukan

$$
X=\frac{\text { Jumlah Skor Hasil Pengumpulan Data }}{\text { Jumlah Butir Soal X Jumlah Point Tertinggi Soal }} \times
$$

\section{Gambar 1. Rumus Penilaian Skor Rata-Rata}

Selanjutnya setelah mendapatkan hasil kualitatif berdasarkan kriteria yang rata-rata keseluruhan, hasil data diperoleh dengan acuan sebagai berikut: kuantitatif ditafsirkan menjadi data

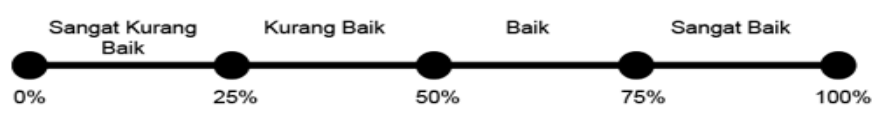

\section{Gambar 2. Garis Rentang Skor Kriteria}

Rentang skor kriteria ketercapaian yang diperoleh dapat dideskripsikan sebagai berikut

\section{Tabel 1. Kriteria Kelayakan Berdasarkan Rating Scale}

\begin{tabular}{cc}
\hline Tingkat Pencapaian & Kualifikasi \\
\hline $\mathbf{0 \%}<$ skor $\leq \mathbf{2 5 \%}$ & Sangat Kurang Baik \\
\hline $\mathbf{2 6 \%}<$ skor $\leq \mathbf{5 0 \%}$ & Kurang Baik \\
\hline $\mathbf{5 1 \%}<$ skor $\leq \mathbf{7 5 \%}$ & Baik \\
\hline $\mathbf{7 6 \%}<$ skor $\leq \mathbf{1 0 0 \%}$ & Sangat Baik \\
\hline
\end{tabular}

\section{HASIL DAN PEMBAHASAN}

Produk yang dihasilkan dari model konseptual ini adalah video motion graphic matematika dengan materi pembelajaran Skala perbandingan untuk siswa kelas V SD. Tujuan dari model konseptual produk ini adalah untuk digunakan sebagai dasar dalam mengembangkan suatu media pembelajaran Matematika yang dapat 
membatu siswa dalam memahami pembelajaran matematika materi skala dengan mudah dan menyenangkan.

Motion graphic interaktif materi skala perbandingan merupakan model konseptual media pembelajaran matematika dalam bentuk video motion graphic yang memperhatikan karakteristik kognitif, bahasa, dan minat siswa usia kelas V SD. Media pembelajaran motion graphic yang dikembangkan mengacu pada kurikulum 2013 khususnya kompetensi dasar matematika 3.4 yaitu menjelaskan skala melalui denah dan 4.4 menyelesaikan masalah yang berkaitan dengan skala pada denah. Perbedaan produk motion graphic skala perbandingan yang peneliti kembangkan dengan produk motion graphic lainnya adalah memiliki konsep interaktif yang mengajak siswa untuk berperan aktif dalam menemukan makna dan fungsi dari pembelajaran skala dalam kehidupan dan siswa dapat berlatih mengerjakan soal pada exercise paper menggunakan rumus yang mudah untuk digunakan dalam menemukan jawaban sesuai instruksi yang ada pada tayangan motion graphic.

Tahapan-tahapan yang dilakukan dalam pengembangan ini meliputi:

\section{Analisis kebutuhan}

Peneliti melaksanakan tahap analisis kebutuhan di SDN Karanggan 01, Gunung Putri, Bogor melalui observasi keadaan sekolah. Berdasarkan hasil observasi diketahui bahwa sekolah tersebut memiliki fasilitas untuk melaksanakan pembelajaran berbasis teknologi namun belum dimanfaatkan dengan optimal. Selanjutnya peneliti melakukan wawancara terhadap guru kelas terkait permasalahan di dalam kelas dan memperoleh informasi bahwa pelaksanaan pembelajaran matematika di kelas $\mathrm{V}$ mengalami kendala pada mata pelajaran matematika materi skala dikarenakan sebagian besar siswa belum mencapai nilai rata-rata minimal sehingga tujuan pembelajaran belum tercapai dengan baik. Hal tersebut dapat terjadi karena kurangnya media pembelajaran yang efektif untuk membantu pemahaman siswa terhadap materi skala, media pembelajaran yang menarik minat belajar siswa dan sesuai dengan karakteristik siswa usia kelas V SD agar tujuan pembelajaran dapat tercapai dengan baik.

Peneliti juga melakukan wawancara terhadap siswa kelas V SD dan memperoleh informasi bahwa siswa mengalami kesulitan dalam memahami 
materi skala dan penggunaaan rumus untuk menyelesaikan soal. Salah satu media pembelajaran yang siswa sukai adalah media pembelajaran dalam bentuk animasi. Media pembelajaran motion graphic merupakan media pembelajaran animasi 2D yang disukai siswa. Siswa kelas V SDN Karanggan 01 menyukai karakter manusia dalam sebuah video animasi pembelajaran dan menyukai tampilan warna-warna cerah seperti biru, kuning, dan ungu. Jenis tulisan yang menarik bagi siswa adalah jenis font chelsea market. Berdasarkan analisis tersebut, media pembelajaran motion graphic yang akan dikembangkan oleh peneliti disesuaikan dengan minat dan kebutuhan siswa tersebut.

\section{Desain}

Setelah melaksanakan tahap analisis kebutuhan, tahap selanjutnya adalah desain. Pada tahap desain peneliti menentukan tujuan pembelajaran, membuat storyboard, dan flowchart penggunaan media. Tujuan pembelajaran dibuat berdasarkan indikator yang dikembangkan dari kompetensi dasar yang akan dicapai.

Adapun tujuan pembelajaran yang dirumuskan peneliti adalah (1) siswa dapat memahami skala sebagai perbandingan antara jarak pada gambar dengan jarak sesungguhnya dengan benar, (2) siswa dapat menentukan ukuran sesungguhnya dengan menggunakan skala denah dengan tepat, (3) siswa dapat membuat sketsa denah suatu tempat dengan skala tertentu dengan benar, (3) siswa dapat memecahkan masalah dalam kehidupan sehari hari yang berkaitan dengan skala dengan tepat.

Langkah selanjutnya setelah menentukan tujuan pembelajaran adalah membuat storyboard. Berikut adalah storyboard yang peneliti kembangkan:

Tabel 2. Storyboard Motion Graphic Interaktif Materi Skala

\begin{tabular}{|l|l|}
\hline \multicolumn{1}{|c|}{ Visual } & \multicolumn{1}{|c|}{ Audio } \\
\hline Opening Judul: & Backsound: \\
A way for me happy. mp4 \\
Voice over: \\
Skala perbandingan
\end{tabular}




\begin{tabular}{|c|c|}
\hline $\begin{array}{l}\text { Penjabaran kompetensi dasar: } \\
\text { Mometensi Dasar }\end{array}$ & $\begin{array}{l}\text { Backsound: } \\
\text { A way for me happy. mp4 } \\
\text { Voice over: } \\
\text { Kompetensi dasar } 3.4 \text { yaitu menjelaskan skala } \\
\text { melalui denah dan } 4.4 \text { menyelesaikan masalah } \\
\text { yang berkaitan dengan skala pada denah. }\end{array}$ \\
\hline Perkenalan karakter: & $\begin{array}{l}\text { Backsound: } \\
\text { A way for me happy. mp4 } \\
\text { Voice over: } \\
\text { Nama saya Pandu, siswa kelas V SD di Bali. }\end{array}$ \\
\hline $\begin{array}{l}\text { Memperhatikan bentuk skala pada suatu peta: } \\
\text { Perhatikan gambar } \\
\text { Peta berikut! }\end{array}$ & $\begin{array}{l}\text { Backsound: } \\
\text { A way for me happy. mp4 } \\
\text { Voice over: } \\
\text { Apakah kamu melihat bentuk skala pada peta } \\
\text { berikut. }\end{array}$ \\
\hline gertian skala dan fungsinya: & $\begin{array}{l}\text { Backsound: } \\
\text { A way for me happy. mp4 } \\
\text { Voice over: } \\
\text { Apa itu skala dan apa fungsinya. }\end{array}$ \\
\hline $\begin{array}{l}\text { Cerita pendek yang menjelaskan mengenai } \\
\text { skala dan fungsinya: }\end{array}$ & $\begin{array}{l}\text { Backsound: } \\
\text { A way for me happy. mp4 } \\
\text { Voice over: } \\
\text { Perhatikan cerita berikut ini, pada suatu hari } \\
\text { pandu mendapat tugas untuk membuat peta dari } \\
\text { sekolah menuju rumah jarak sebenarnya dari } \\
\text { sekolah ke rumah adalah } 200 \mathrm{~m} \text {. }\end{array}$ \\
\hline $\begin{array}{l}\text { Permasalahan pertama yang muncul dalam alur } \\
\text { cerita: }\end{array}$ & $\begin{array}{l}\text { Backsound: } \\
\text { A way for me happy. mp4 } \\
\text { Voice over: } \\
\text { Bagaimana cara membuat denah pada kertas } \\
\text { ukuran } 30 \times 10 \mathrm{~cm} \text {. }\end{array}$ \\
\hline 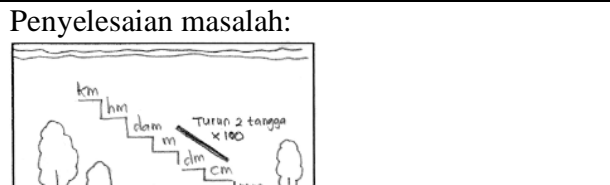 & $\begin{array}{l}\text { Backsound: } \\
\text { A way for me happy. mp4 } \\
\text { Voice over: } \\
\text { Mari kita ubah } 200 \mathrm{~m} \text { menjadi } \mathrm{cm} \text {. }\end{array}$ \\
\hline 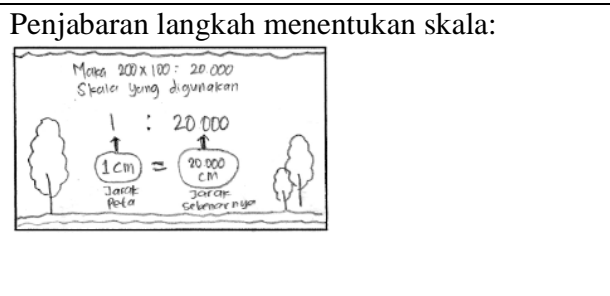 & $\begin{array}{l}\text { Backsound: } \\
\text { A way for me happy. mp4 } \\
\text { Voice over: } \\
\text { maka } 200 \text { x } 100=20.000 \mathrm{~cm} \text {, skala yang dapat } \\
\text { pandu gunakan adalah } 1: 20.000 \text {, yang artinya } 1 \\
\text { cm jarak pada denah mewakili } 20.000 \mathrm{~cm} \text { jarak } \\
\text { sebenarnya. }\end{array}$ \\
\hline Permasalahan kedua: & $\begin{array}{l}\text { Backsound: } \\
\text { A way for me happy. mp4 } \\
\text { Voice over: } \\
\text { Namun dengan menggunakan skala } 1: 20.000 \\
\text { gambar peta yang pnadu buat terlalu kecil. }\end{array}$ \\
\hline
\end{tabular}


Jurnal Parameter Volume 32 No. 1

DOI : doi.org/10.21009/parameter.321.04

P-ISSN : 0216-261X E-ISSN : 2620-9519

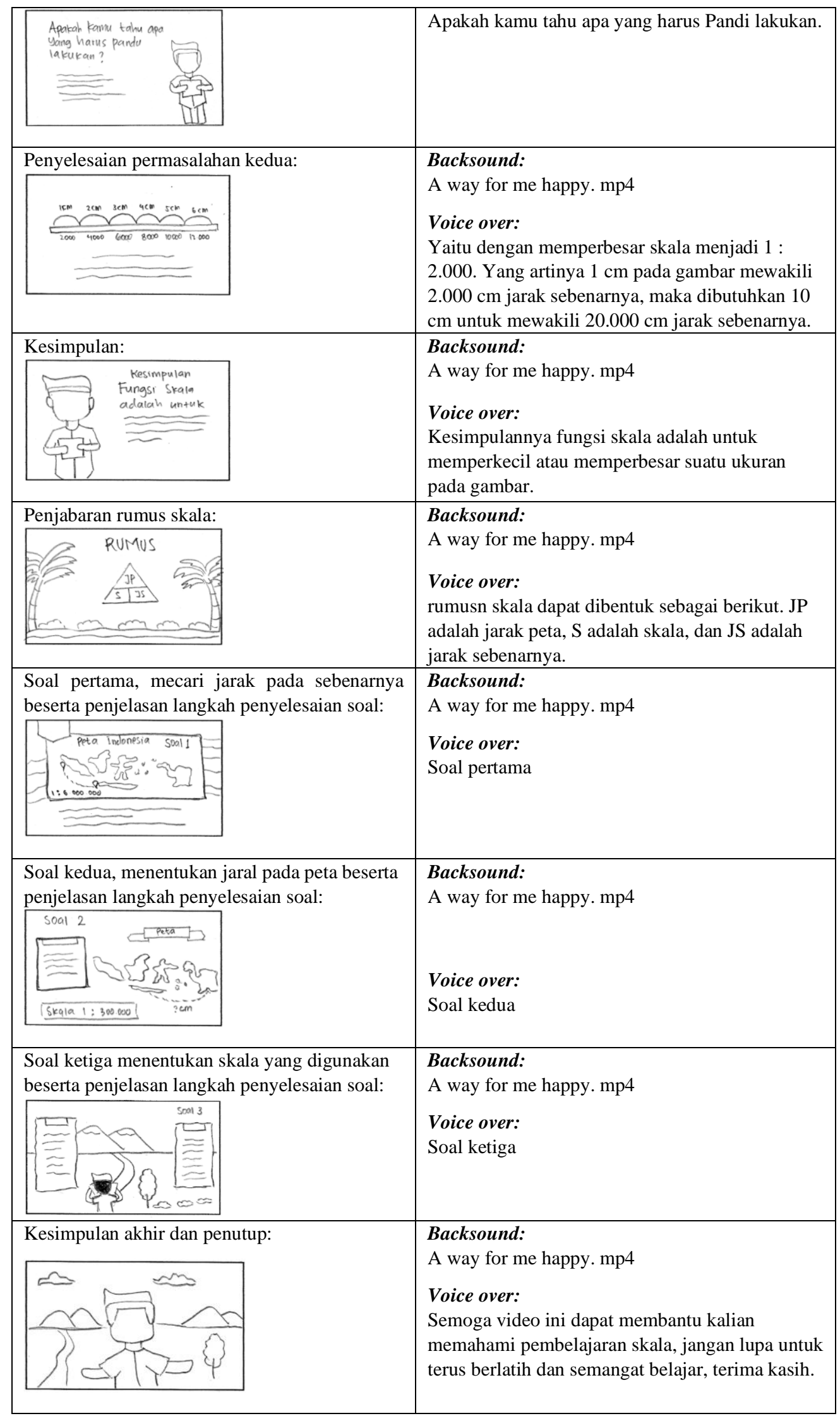


Setelah motion graphic selesai berada di dalam kelas untuk dibuat selanjutnya adalah membuat memudahkan guru saat flowchart penggunaan media menggunakannya Bersama siswa dan pembelajaran motion graphic di dalam agar tujuan dari penggunaan media kelas. Pembuatan flowchart dibutuhkan pembelajaran motion graphic dapat sebagai petunjuk sistem penggunaan tercapai sesuai harapan. media pembelajaran motion graphic saat

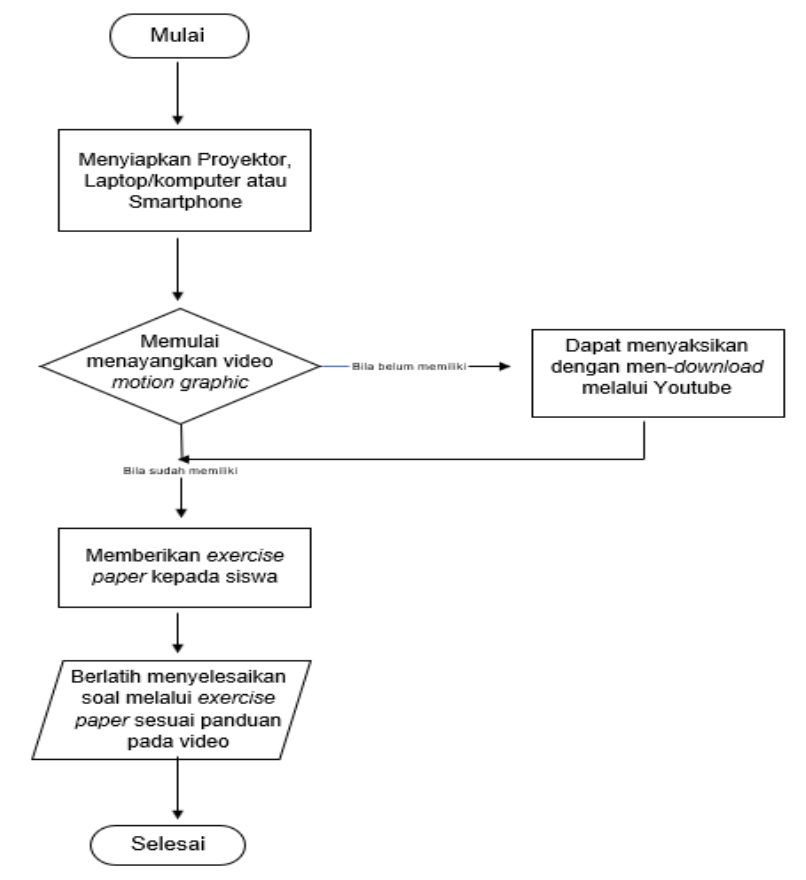

\section{Gambar 3. Flowchart Penggunaan Motion Graphic di Dalam Kelas}

\section{Pengembangan dan implementasi}

Tahap berikutnya setelah tahap desain adalah tahap pengembangan dan implementasi. Tahap pengembangan merupakan tahap dilakukannya proses produksi produk yang dikembangkan. Pada tahap ini produk media motion graphic di produksi dimulai dari pembuatan karakter animasi, background, tipografi dan desain lay out setiap scene dengan bantuan software adobe ilustrator sesuai dengan storyboard yang telah dibuat kemudian dilakukan proses pewarnaan dan simpan dalam format png.

Setelah semua desain dari setiap scene pada storyboard telah dibuat dan diberi pewarnaan dalam bentuk vektor menggunakan adobe ilustrator maka langkah selanjutnya adalah proses 
penganimasian atau menggerakkan objek diam menggunakan software Adobe After Effects CC 2019. Selanjutnya setelah proses menggerakkan objek diam menjadi suatu animasi bergerak maka animasi memasuki proses rendering untuk menjadikan output akhir dalam format MPE4 menggunakan adobe media encorder.

Proses berikutnya yaitu merekam suara untuk mengisi suara karakter pada animasi, prosesnya ini disebut juga proses dubbing. Suara yang telah direkam akan dimasukan ke dalam software adobe premier untuk digabungkan dengan animasi proses ini memasuki proses editting. Selain memasukkan suara dubbing, efek suara tambahan lainnya seperti backsound juga dimasukkan ke dalam software adobe premier untuk kemudian dijadikan satu kesatuan melalui proses rendering dengan format akhir MPEG4.

Proses terakhir dalam produksi yaitu memasukkan file motion graphic dengan format MP4 ke dalam CD untuk kemudian diburning sehingga motion graphic dapat diputar dengan mudah menggunakan laptop, komputer atau DVD. Produk motion graphic juga dilengkapi dengan exercise paper untuk melatih kemampuan siswa dalam mengerjakan soal sesuai dengan instruksi pada video motion graphic. Exercise paper terbagi menjadi 4 halaman, yaitu pada halaman pertama cover, halaman kedua menyelesaikan soal untuk menentukan jarak sebenarnya, halaman ketiga berlatih menyelesaikan soal untuk menentukan jarak pada peta, dan halaman keempat berlatih menyelesaikan soal untuk menentunkan skala yang digunakan.

Implementasi adalah tahap yang dilaksanakan setelah proses pengembangan media telah dilakukan. Media pembelajaran motion graphic yang telah diproduksi akan di implementasikan untuk mengetahui pengaruh keefektifannya melalui uji validitas kepada ahli media, ahli materi, dan ahli bahasa menggunakan kuesioner tertutup dan terbuka. Setelah media motion graphic telah diproduksi selanjutnya media melalui tahap expert review oleh ahli materi, ahli bahasa, dan ahli media. Rekapitulasi Perolehan penilaian rata-rata keseluruhan expert review adalah sebagai berikut: 
Tabel 3. Hasil Analisis Data Rekapitulasi Expert Review

\begin{tabular}{cc}
\hline Validator & Persentase \\
\hline Ahli materi & $90,63 \%$ \\
\hline Ahli bahasa & $96,59 \%$ \\
\hline Ahli media & $98,21 \%$ \\
\hline Rata-rata & $95,14 \%$ \\
\hline
\end{tabular}

Berdasarkan hasil validasi yang telah dilakukan oleh expert review dapat disimpulkan bahwa media pembelajaran motion graphic matematika materi Skala mendapat rata-rata kelayakan produk sebesar 95,14\% dan dapat dikategorikan "Sangat Baik".
Berikut ini merupakan bagan model konseptual yang menunjukan hubungan antara teori yang digunakan untuk membentuk kerangka konsep yang telah disesuaikan dengan variabel yang relevan dengan masalah yang terdapat di lapangan.

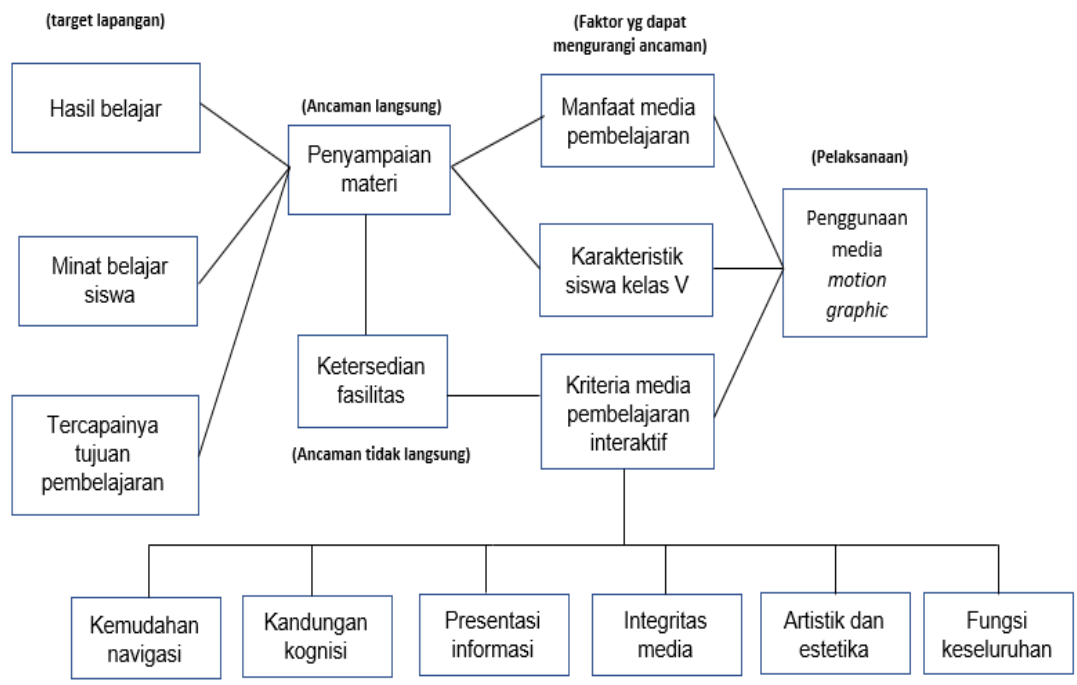

Gambar 4. Model Konseptual Media Motion Graphic 
Berdasarkan kerangka bagan model konseptual tersebut menjelaskan bahwa terdapat beberapa kondisi awal lapangan yang peneliti temukan di SDN Karanggan 01 yang kemudian akan dijadikan target untuk ditingkatkan kualitasnya diantaranya yaitu hasil belajar, minat belajar dan tercapainya tujuan pembelajaran khususnya pada mata pelajaran matematika. Berdasarkan hasil observasi ditemukan permasalahan langsung yang menyebabkan kondisi lapangan belum ideal yaitu cara guru dalam menyampaikan materi pembelajaran. Selanjutnya, terdapat permasalahan tidak langsung dalam penyampaian materi yaitu ketersedian fasilitas seperti media pembelajaran yang digunakan dan fasilitas pendukung untuk mengopersikan media pembelajaran.

Berdasarkan permasalahan tersebut peneliti menemukan beberapa faktor yang dapat mengatasi permasalahan langsung dan tidak langsung yaitu faktor dalam mengembangkan media pembelajaran sebagai perantara penyampaian materi dengan memperhatikan beberapa faktor diantaranya manfaat media pembelajaran, karakteristik siswa kelas $\mathrm{V}$ SD, dan kriteria penilaian media interaktif yang terdiri dari enam aspek yang harus diperhatikan dalam mengembangakan suatu media pembelajaran interaktif yaitu kemudahan navigasi, kandungan kognisi, presentasi informasi, integritas media, artistik dan estetika, fungsi keseluruhan media sehingga pentingnya dikembangkan media pembelajaran motion graphic untuk menanggulangi permasalahan yang terdapat di SDN Karanggan 01 agar terlaksananya pembelajaran yang lebih baik.

\section{PEMBAHASAN}

Model konseptual media pembelajaran motion graphic matematika materi skala dilakukan berdasarkan permasalahan yang terjadi di SDN Karanggan 01 salah satunya yaitu kesulitan belajar yang dialami oleh siswa kelas $\mathrm{V}$ pada pembelajaran matematika khususnya materi skala. Kurangnya ketersediaan media pembelajaran pada materi tersebut yang sesuai dengan minat dan kebutuhan siswa membuat peneliti tergerak untuk mengembangkan media pembelajaran motion graphic yang sesuai dengan karakteristik belajar siswa usia kelas V SD. Berdasarkan wawancara yang dilakukan oleh guru kelas V SDN 
Karanggan 01 mengatakan bahwa beberapa kali telah memanfaat media pembelajaran dalam bentuk video yang tersedia di internet dalam proses pembelajaran di kelas, namun media pembelajaran video yang digunakan masih terdapat beberapa kekurangan diantaranya seperti kualitas gambar pada video yang kurang baik, isi materi yang kurang sesuai dengan tujuan pembelajaran, penggunaan kalimat yang sulit dipahami oleh siswa, dan suara dubbing yang kurang terdengar dengan jelas. Menanggapi hal tersebut peneliti mengembangkan media pembelajaran dalam bentuk video yaitu motion graphic yang sesuai dengan kebutuhan pembelajaran siswa.

Motion graphic yang dikembangkan oleh peneliti memiliki keunggulan yang berbeda dengan media pembelajaran motion graphic lainnya yaitu konsep motion graphic dibuat interaktif dan dilengkapi dengan exercise paper untuk melatih kemampuan siswa dalam menyelesaikan soal sesuai dengan instruksi pada video, sehingga siswa tidak hanya menonton tetapi turut mencoba melakukan untuk menemukan penyelesaian soal sehingga siswa akan lebih memahami materi yang disampaikan dalam video motion graphic. Karakter animasi, pewarnaan, dan bahasa yang digunakan dalam motion graphic juga disesuaikan dengan tahap perkembangan siswa usia kelas $\mathrm{V}$ dengan harapan tujuan pembelajaran dapat tercapai dengan baik melaui penggunaan media pembejaran motion graphic yang peneliti kembangkan. Format akhir media motion graphic adalah berbentuk format MPEG4 yang dapat dioperasikan dengan mudah menggunakan komputer, handphone, dan DVD player. Produk akhir motion graphic dimasukan kedalam CD dan dikemas dalam packaging dilengkapi exercise paper didalamnya.

Model konseptual media motion graphic matematika materi skala untuk siswa kelas $\mathrm{V}$ ini mengacu pada kurikulum 2013 kompetensi dasar matematika 3.4 dan 4.4. Metode pengembangan yang dilaksanakan menggunakan metode Hannafin dan Pack dengan melalui 3 tahap yaitu tahap analisis kebutuhan yang dilakukan dengan melakukan observasi kondisi sekolah, wawancara terhadap guru kelas dan siswa untuk mendapatkan informasi kebutuhan belajar siswa. Tahap selanjutnya, setelah analisis kebutuhan yaitu tahap desain, pada tahap ini peneliti merumuskan tujuan 
pembelajaran, membuat storyboard motion graphic yang akan dikembangkan, dan flowchart penggunaan media motion graphic di dalam kelas. Setelah itu, peneliti melaksanakan tahap ketiga yaitu pengembangan dan implementasi, pada tahap ini dilaksanakan pembuatan produk menggunakan software yang dibutuhkan dan setelah produk jadi akan di laksanakan implementasi dengan melakukan validasi media kepada ahli materi, ahli bahasa, dan ahli media untuk menguji kelayakan penggunaan media motion graphic.

Validasi media motion graphic dilakukan kepada para ahli menggunakan kuisioner. Penilaian media oleh ahli materi diperoleh skor rata-rata kelayakan produk sebesar 90,63\% artinya media termasuk kriteria sangat baik (SB), oleh ahli bahasa memperoleh skor rata-rata kelayakan produk sebesar 96,59\% yang masuk pada kriteria sangat baik (SB), dan penilaian media oleh ahli media diperoleh skor rata-rata kelayakan produk sebesar 98,21\% juga termasuk kategori sangat baik (SB), berdasarkan hasil data yang diperoleh dari expert review didapatkan rata-rata penilaian kelayakan produk yaitu sebesar 95,14\% artinya secara rata-rata keselurahan penilaian dari para ahli dapat disimpulkan bahwa media pembelajaran motion graphic matematika materi skala berada pada kategori "Sangat Baik" (SB).

Model konseptual media pembelajaran motion graphic interaktif matematika pada materi Skala untuk siswa kelas V SD yang peneliti temukan menunjukkan bahwa media motion graphic dapat menjadi solusi terhadap beberapa permasalahan pembelajaran matematika yang terdapat di lapangan, diantaranya yaitu pencapaian hasil belajar, minat belajar siswa, dan tujuan pembelajaran yang belum tercapai dengan baik di SDN Karanggan 01.

Berdasarkan hasil wawancara terhadap guru dan siswa kelas V, Peneliti menemukan salah satu faktor penyebab utama terjadinya permasalahan tersebut yaitu belum efektifnya penyampaian materi pembelajaran oleh guru di dalam kelas. Dalam hasil penelitian Eko dkk mengatakan bahwa metode penyampaian materi oleh guru sangat berpengaruh terhadap pencapaian hasil belajar siswa. Metode pembelajaran berpusat pada guru menjadikan siswa pasif karena siswa tidak mengeksplorasi materi subjek itu sendiri (Pricahyo, 2018). Penyampaian materi pembelajaran 
matematika materi skala di SDN Karanggan 01 belum menggunakan media pembelajaran yang baik dan masih berpusat pada guru.

Selain faktor penyebab utama peneliti juga menemukan faktor lain yang menyebabkan permasalah tersebut terjadi yaitu belum optimalnya pemanfaatan fasilitas teknologi di sekolah yang dapat menunjang inovasi pembejalaran di dalam kelas. Leonard dalam penelitiannya mengatakan bahwa pemanfaatan teknologi dalam dunia pendidikan diantaranya dapat membantu dalam proses pembelajaran (Sahelatua, 2018). Melalui bantuan teknologi materi bahan ajar dapat ditampilkan dalam berbagai format dan bentuk yang lebih menarik dan interaktif sehingga siswa lebih tertarik dan termotivasi untuk mengikuti proses pembelajaran.

Terdapat beberapa hal yang perlu diperhatikan untuk mengatasi permasalahan penyampaian materi pada siswa diantaranya yaitu manfaat media pembelajaran dan karakteristik siswa kelas V SD. Rivdya menyatakan pada hasil penelitiannya "media dalam kegiatan proses pembelajaran berfungsi sebagai alat untuk mempermudah pemahaman siswa dan mempermudah mengkomunikasikan hal-hal yang rumit"( Eliza, 2010). Setiap media memiliki karakteristik dan kekhasannya masing-masing menyesuaikan tujuan penggunaan media pembelajaran. Saat penyampaikan materi pembelajaran guru harus menggunakan media pembelajaran yang sesuai dengan manfaat media pembelajaran itu sendiri yaitu : (1) mengatasi perbedaan pengalaman, (2) mengonkretkan konsep-konsep yang abstak, (3) mengatasi keterbatasan, (4) interaksi langsung, (5) menghasilkan keseragaman pengamatan , menanamkan konsep dasar yang benar, konkret, dan realitias, (7) merangsang dan membangkitkan motivasi untuk belajar, (8) membangkitkan keinginan dan minat belajar, (9) memberikan pengalaman integral.

Hal lain yang penting untuk diperhatikan adalah pengembangan media pembelajaran harus sesuai dengan karakteristik perkembangan kognitif dan perkembangan bahasa siswa. Angganingrum dalam penelitiannya menyatakan video yang digunakan dalam penelitiannya sesuai dengan karakteristik siswa sehingga siswa menjadi lebih mudah untuk memahami materi yang disajikan menggunakan media video (Hapsari, 2019). Penyampaian materi pembelajaran akan 
lebih efektif dan mudah dipahami jika disesuaikan dengan karakteristik siswa yang menjadi target sasaran penggunaan media pembelajaran.

Selanjutnya faktor yang berkaitan dengan ketersediaan fasilitas untuk menggunakan suatu media guna menyampaikan materi pembelajaran adalah kriteria media pembelajaran. Kriteria media pembelajaran interaktif dapat dijadikan acuan penilaian suatu media pembelajaran yang baik. Kriteria tersebut mencangkup penilaian beberapa aspek yang perlu untuk diperhatikan dalam mengambangkan suatu media media pembelajaran diantaranya yaitu: (1) kemudahan navigasi, (2) kandungan kognisi, (3) presentasi informasi, (4) integritas media, (5) artistik dan estetika, (6) fungsi keseluruhan. Bulu juga menyimpulkan dalam hasil temuannya motion graphic yang dilengkapi dengan gambar, animasi, musik, suara terbukti dapat menarik perhatian siswa dan memotivasi untuk belajar. Dengan memperhatikan manfaat media pembelajaran, karakteristik siswa, dan kriteria peniliaian media interaktif dalam mengembangkan suatu media pembelajaran dapat menghasilkan suatu media pembelajaran yang sesuai dengan kebutuhan guru dan siswa.
Salah satunya media pembelajaran yang dapat mengatasi permasalahan tersebut adalah media motion graphic interaktif Matematika materi Skala. Temuan ini konsisten dengan hasil penelitian Lanto dkk yang menyatakan temuan dalam penelitiannya bahwa penggunaan media motion graphic dapat meningkatkan prestasi belajar siswa, dilihat berdasarkan nilai rata-rata sebelum menggunakan media yaitu 57,60 dan setelah menggunakan media motion graphic nilai rata-rata siswa meningkat menjadi 79,20 (Amali, 2020). Selain itu, proses pembelajaran di dalam kelas yang dikombinasikan dengan penggunaan media pembelajaran video interaktif dan instruksi guru terbukti dapat lebih efektif dalam meningkatkan pengetahuan dan keterampilan siswa. Dalam percobaannya penggunaan media pembelajaran video interaktif membuat siswa antuasias saat proses pembelajaran (Islam, 2014).

Penyampaian materi pembelajaran menggunakan media animasi dapat meningkatkan daya ingat siswa terhadap materi pembelajaran (Olabode, 2014). Penggunaan video pembelajaran pada pembelajaran matematika lebih menekankan pada aspek kognitif untuk mencapai tujuan pembelajaran 
matematika daripada aspek afektif (Lailan, 2018) Namun, meskipun penggunaan video pembelajaran menekankan pada aspek kognitif, video pembelajaran juga dapat meningkatkan motivasi dan minat siswa dalam proses pembelajaran sehingga tujuan pembelajaran akan lebih mudah tercapai.

Penelitian ini menemukan bahwa media pembelajaran yang dapat menjadi solusi terhadap permasalahan terhadap hasil belajar, minat belajar siswa, tujuan pembelajaran yang belum tercapai dengan baik adalah dengan menggunakan media pembelajaran yang memperhatikan kesesuaian dengan manfaat suatu media, karakteristik siswa yang meliputi karakteristik kognitif dan bahasa juga kriteria penilaian media interaktif disesuaikan dengan fasilitas yang terdapat di sekolah. Media motion graphic akan efektif digunakan jika sekolah memiliki fasilitas teknologi untuk pengoperasian media motion graphic seperti perangkat komputer atau laptop, proyektor dan pengetahuan guru dalam penggunaannya. Dalam kondisi pandemi seperti saat ini yang mengharuskan siswa untuk melakukan pembelajaran jarak jauh media motion graphic dapat menjadi solusi penyampaian pembelajaran jarak jauh oleh guru menggunakan yang dapat diakses oleh siswa menggunakan handphone ataupun laptop di rumah.

Media pembelajaran motion graphic matematika materi skala yang dikembangkan memiliki beberapa kelebihan diantaranya yaitu (1) media dapat digunakan secara mandiri maupun kelompok, (2) dapat digunakan kapan saja dan dimana saja, (3) media mudah dioperasikan (4) memvisualisasikan materi pembelajaran dengan konkret, (5) siswa dapat berperan aktif saat menggunakan media, (6) memberikan pengalaman belajar yang baru bagi siswa, (7) media disesuaikan dengan tahapan perkembangan siswa.

Dalam model konseptual media pembelajaran motion graphic matematika materi skala, peniliti berusaha semaksimal mungkin untuk menghasilkan media motion graphic yang baik dan layak untuk digunakan, namun tidak dapat dipungkiri bahwa saat proses pengembangan media di masa pandemi Covid-19 yang mengharuskan untuk melakukan physical distancing, terdapat beberapa keterbatasan dalam penelitian ini. Diantaranya yaitu (1) Peneliti tidak melakukan uji coba perorang (One-to-One Tryout), uji coba kelompok kecil (Small Group Tryout), 
dan uji coba lapangan (Field Tryout, (2) Peneliti tidak melakukan evaluasi sumatif pada media, (3) Subjek penelitian hanya dilakukan dilakukan pada satu sekolah sehingga hasil tidak dapat digeneralisasikan.

\section{PENUTUP}

Penelitian model konseptual ini menghasilkan sebuah produk berupa media pembelajaran video motion graphic interaktif matematika yang memuat materi pembelajaran skala perbandingan untuk siswa kelas V SD. Tujuan dari model konseptual produk ini adalah mengembangkan suatu media pembelajaran yang dapat membantu siswa dalam memahami pembelajaran matematika materi skala dengan mudah dan menyenangkan.

Model pengembangan yang digunakan dalam penelitan pengembangan ini adalah model Hannafin dan Pack. Terdapat tiga tahap pada model pengembangan Hannafin dan Peck yaitu 1) Analisis kebutuhan, pada tahap ini peneliti menganalisis kebutuhan melalui observasi sekolah, wawancara terhadap guru kelas dan wawancara terhadap siswa. 2) Desain, pada tahap ini peneliti merumuskan tujuan pembelajaran, membuat storyboard, dan flowchart penggunaan media di dalam kelas. 3) Pengembangan dan Implementasi, pada tahap ini penelitian melaksanakan pengembangan produk menggunakan software Adobe After Effects CC 2019 dan software pendukung lainnya, setelah produk selesai dikembangkan maka peneliti melaksanakan implementasi dengan memvalidasi produk kepada para ahli.

Model konseptual media pembelajaran motion graphic ini melalui tahap expert review yang melibatkan 3 ahli yaitu ahli materi, ahli bahasa, dan ahli media. Penilaian dari ahli materi memperoleh nilai rata-rata sebesar 90,63\%. Penilaian dari ahli bahasa memperoleh nilai rata-rata sebesar 96,59\% dan Penilaian dari ahli media memperoleh nilai rata-rata sebesar 98,21\%. Berdasarkan penilaian para ahli tersebut didapatkan rata-rata penilaian kelayakan media keseluruhan yaitu sebesar 95,14\% dan masuk kedalam kategori "Sangat Baik" yang artinya layak untuk digunakan.

Model konseptual media motion graphic interaktif Matematika pada materi Skala menggunakan Adobe After Effects CC 2019 untuk siswa kelas V sekolah dasar yang peneliti temukan berdasarkan identifikasi masalah yang 
terjadi di SDN Karanggan 01 Gunung Putri, Bogor menunjukan bahwa terdapat faktor-faktor relevan yang menghantarkan pentingnya pengembangan dan penggunaan media pembelajaran motion graphic di sekolah dasar. Kondisi awal lapangan yang peneliti temukan akan dijadikan target untuk ditingkatkan kualitasnya, diantaranya yaitu permasalahan terhadap hasil belajar, minat belajar dan tercapainya tujuan pembelajaran khususnya pada mata pelajaran matematika. Berdasarkan hasil analisis ditemukan faktor permasalahan langsung yang menyebabkan kondisi lapangan belum ideal yaitu cara guru dalam menyampaikan materi pembelajaran dan permasalahan tidak langsung yaitu ketersediaan fasilitas di sekolah.

Berikutnya ditemukan faktorfaktor yang dapat menanggulangi permasalahan tersebut yaitu dengan memperhatikan manfaat media pembelajaran, karakteristik siswa kelas $\mathrm{V}$, dan kriteria media pembelajaran yang terdiri dari kemudahan navigasi, kandungan kognisi, presentasi informasi, integritas media, artistik dan estetika, fungsi keseluruhan media. Peneliti menemukan bahwa salah satu media pembelajaran yang dapat menjadi solusi terdapat permasalahan tersebut adalah penggunaan media motion graphic yang memperhatikan kesesuaian manfaat suatu media, karakteristik siswa yang meliputi karakteristik kognitif dan bahasa juga kriteria penilaian media interaktif disesuaikan dengan fasilitas yang terdapat di sekolah dengan begitu media pembelajaran motion graphic akan efektif digunakan.

\section{DAFTAR PUSTAKA}

Amali, L. N. (2020). Motion graphic animation video as alternative learning media. Jambura Journal of Informatika, 2(1), 29, 23-30.

Arindi, K. (2019). Motion graphic mitigasi bencana gempa bumi untuk anak SD di kota Padang. Jurnal Desain Komunikasi Visual, 8(3), 1-17.

Eliza, R. (2010). Media pembelajaran sebagai sarana komunikasi matematika di sekolah dasar. $E$ Journal IAIN Batusangkar, 12(2), 153.

Gusman, N. M., \& Marlini. (2018). Pembuatan motion graphic untuk memperkenalkan perpustakaan kepada siswa sekolah dasar dalam bentuk video. Jurnal Ilmu Informasi, 7(2), 88-94. 
Hamzah, A. (2019). Metode Penelitian dan Pengembangan (Research and Development). Malang: Literasi Nusantara.

Hapsari, A. S. (2019). Motion graphic animation videos to improve the learning outcomes of elementary school students. European Journal Of Educational Research, 8(4), 1245-1255.

Islam, M.B., dkk. (2014). Child education through animation: an experimental study. International Journal of Computer and Animation (UCGA), 4(4), 43-52.

Lailan, O. N. (2018). The effect of using video media in mathematics learning on student cognitive and affective aspect. AIP Conference Proceedings, (1), 1-4.

Miranti, G. D. (2017). Perancangan animated motion graphic sebagai media alternatif pembelajaran anak tunagrahita. e-Proceeding of Art \& Design, 4(3), 634-643.

Oktaviani, N. (2018). Perancangan video infografis bahaya merokok untuk anak SD menggunakan teknik motion graphics. Jurnal Desain Komunikasi Visual Asia,
$1(2), 65-76$.

Olabode, O., \& Oginni, O. I. (2014). Effectiveness of animation and multimedia teaching on student performance in science subject. British Journal of Education, Society \& Behavioural Science, 4(2), 208.

Pricahyo, E. W. (2018). Development of motion graphic animation video in elementary school. Atlantis Press, $165,121-125$.

Purwanti, A., \& Haryanto. (2015). Pengembangan motion graphic pembelajaran mata pelajaran Pendidikan Kewarganegaraan Kelas I Sekolah Dasar. Jurnal Inovasi Teknologi Pendidikan, 2(2), 190-200.

Sahelatua, L. S. (2018). Kendala guru memanfaatkan media IT dalam pembelajaran di SDN Pagar Air Aceh Besar. Jurnal Ilmiah Pendidikan Guru Sekolah Dasar, 3(2), 131-140. 